\title{
Motivasi Belajar Ditinjau dari Status Pekerjaan Ibu
}

\author{
Ni Putu Pradnya Paramitha Shinta Devi ${ }^{1}$, Ni Wayan Suniasih ${ }^{1}$, \\ I. B. Gede Surya Abadi ${ }^{2}$ \\ ${ }^{123}$ Pendidikan Guru Sekolah Dasar, Universitas Pendidikan Ganesha \\ Singaraja, Indonesia \\ e-mail: putu.pradnya.paramitha@undiksha.ac.id ${ }^{1}$, niwayan.suniasih@undiksha.ac.id², \\ idabagusgedesurya.abadi@undiksha.ac.id ${ }^{3}$
}

\begin{abstract}
Abstrak
Secara teoretis antara ibu pekerja dan rumah tangga tentunya memiliki perbedaan khususnya pada tanggung jawab yang diemban serta waktu dengan anak yang disinyalir menyebabkan perbedaan motivasi belajar pada diri siswa. Tujuan penelitian ini adalah untuk menentukan perbedaan yang signifikan motivasi belajar siswa kelas IV antara ibu pekerja dan ibu rumah tangga dengan menggunakan rancangan "ex post facto" dengan jenis kausal komparatif atau hubungan sebab akibat. Populasi dalam penelitian ini terdiri dari 12 kelas dalam 8 sekolah dengan jumlah siswa selurunya adalah 392 siswa. Penentuan sampel digunakan teknik purposive sampling. Berdasarkan kriteria yang telah ditetapkan, diperoleh sampel siswa ibu pekerja sebanyak 74 orang dan ibu rumah tangga sebanyak 74 orang. Data yang dikumpulkan berkaitan dengan motivasi belajar siswa yang diperoleh melalui penyebaran angket dan dianalisis menggunakan uji-t untuk penelitian empiris $(n 1=n 2)$ dengan data motivasi belajar berdistribusi normal serta varian homogen. Berdasarkan hasil analisis data diperoleh harga thitung $=4,352$ dan pada taraf signifiansi $5 \%$ dengan derajat kebebasan $(74+74-2)=146$ diperoleh tabel $=1,976$. Hal ini berarti thitung $=4,352>t_{\text {tabel }}=$ 1,976. Dengan demikian dapat disimpulkan bahwa terdapat perbedaan yang signifikan motivasi belajar siswa kelas IV antara ibu pekerja dan ibu rumah tangga.
\end{abstract}

Kata kunci: motivasi belajar, status pekerjaan ibu.

\begin{abstract}
Theoretically, the working mothers and households certainly have differences, especially in the responsibilities they carry and the time with children who are thought to cause differences in students' motivation to learn. The purpose of this study was to determine a significant difference in class IV student motivation between working mothers and housewives using the "ex post facto" design with comparative causal types or causal relationships. The population in this study consisted of 12 classes in 8 schools with a total of 392 students. Determination of the sample used purposive sampling technique. Based on the established criteria, a sample of 74 working mother students and 74 housewives were obtained. The data collected is related to students' learning motivation obtained through questionnaires and analyzed using t-test for empirical research $(\mathrm{n} 1=\mathrm{n} 2)$ with learning motivation data normally distributed and homogeneous variants. Based on the results of data analysis, the value of $t_{\text {count }}=4.352$ and at the significance level of $5 \%$ with degrees of freedom $(74+74-2)=146$ obtained table $=1.976$. This means that $t_{\text {count }}=4.352>$ table $=1.976$. Thus it can be concluded that there is a significant difference in learning motivation of fourth grade students between working mothers and housewives at SD Gugus Kompyang Sujana Denpasar Utara in Academic Year 2019/2020.
\end{abstract}

Keywords: learning motivation, mother's employment status.

\footnotetext{
*Corresponding author.

Received 20 April 2020, Accepted 20 Juni 2020; Available online 5 Juli 2020

(C) 2020 MI All Rights Reserved
} 


\section{Pendahuluan}

Keluarga merupakan komponen maupun elemen paling kecil dari masyarakat yang dipersatukan karena adanya sebuah pernikahan dan hubungan darah. Lingkungan keluarga merupakan tempat terjadinya proses pengasuhan serta pendidikan terhadap anak dengan orang tua sebagai figur yang paling berperan didalamnya (Tarbiyah, 2017). Ayah sebagai pemimpin keluarga semestinya dapat mengayomi, menjadi model mengenai sikap kepimimpinan dan bertanggung jawab terhadap keluarganya (Hidayati, 2002). Sebagai pemimpin keluarga, pada hakekatnya ayah berkewajiban mencari nafkah untuk memenuhi kebutuhan ekonomi keluarganya (Purbasari \& Putri, 2015). Sehubungan dengan tugas dan kodrat ayah tersebut, dapat diyakini ayah memiliki waktu yang relatif lebih sedikit untuk berada dirumah. Sehinga dengan keadaan yang demikian, maka sosok ibulah yang sepatutnya memiliki waktu penuh atau lebih banyak dalam mengasuh, merawat dan mendidik anak baik itu berupa pengajaran, pemberian dorongan atau perhatian, pembentukan tingkah laku, pendidikan karakter, moral, kepribadian maupun kecerdasan yang akan dibawa anak dalam berinteraksi langsung dengan masyarakat luas (Wiratri, 2018). Khususnya dalam hal kewajiban mendidik anak acap kali ibu mengesampingkan dengan berbagai alasan seperti sibuk bekerja, mengurus rumah tangga atau memandang pendidikan di sekolah saja telah cukup. Pandangan tersebut tidak sepatutnya dilanjutkan, seorang ibu tidak dapat lepas tangan meski anak telah mengenyam pendidikan di sekolah sebagai lembaga pendidikan formal, mengingat keberhasilan pendidikan anak bukan semata hanya tanggung jawab pemerintah dan lembaga pendidikan saja, namun termasuk juga ibu dalam keluarga yang berperan sebagai lembaga pendidikan informal (Qmar, 2017). Ibu sebagai orang terdekat bagi anak, semestinya ikut terlibat langsung dalam mendidik di rumah guna menunjang keberhasilan anak dalam mengenyam pendidikan dan keberhasilannya kelak nanti (Apreviadizy, 2014). Ibu merupakan motivator bagi anak di rumah (Akbar, 2016). Salah satu hal mendasar yang semestinya diupayakan ibu terhadap anaknya dalam menunjang keberhasilan di bidang pendidikan adalah dengan menumbuhkan motivasi belajar.

Pada dasarnya motivasi belajar berupa dorongan, stimulus ataupun hasrat yang berpangkal pada diri siswa (Oktiani, 2017). Timbulnya dorongan tersebut dapat dipengaruhi oleh faktor instrinsik dan faktor ekstrinsik (Suprihatin, 2015). Cita-cita merupakan salah satu faktor instrinsik yang mendorong timbulnya motivasi belajar (Fauziah, 2017). Selain itu, diperlukan juga dukungan dari luar sebagai faktor ekstrinsik sehingga timbulnya motivasi belajar seperti kelurga dengan mengupayakan lingkungan belajar yang memberi dukungan (kondusif) bagi keberlangsungan proses belajar siswa (Astriyani, 2018). Pihak yang berperan agar terciptanya lingkungan belajar yang kondusif selain guru disekolah ialah ibu selaku keluarga dan orang terdekat bagi anak (Uno, 2019). Ketersediaan lingkungan yang mendukung dapat mendorong tumbuhnya motivasi belajar.

Tumbuhnya motivasi belajar pada anak sangatlah penting dan dapat memberikan pengaruh yang signifikan terhadap keberhasilan pendidikan anak (Emda, 2017). Proses pembelajaran akan tercapai, jika didukung oleh adanya motivasi untuk belajar (Riswanto, 2017). Pandangan tersebut dipertegas oleh hasil penelitian yang dilakukan (Muhajis, 2018) dengan temuan bahwa motivasi belajar mampu memprediksi prestasi belajar siswa sebesar $10 \%$ atau dengan nilai koefisien korelasi $(r)$ sebesar 0,10 disamping faktor-faktor lain yang juga menentukan. Hal ini dipandang penting, mengingat motivasi belajar bukan hanya sekedar pendorong anak untuk belajar, namun juga memperlancar proses pencapaian prestasi belajar anak (Darmawati, 2013). Peran ibu dalam menumbuhkan motivasi belajar pada anak tentunya 
tidak dengan cara-cara yang membuat anak terpaksa atau tertekan untuk belajar, namun lebih pada memberi dorongan, pendampingan, perhatian, rasa nyaman, menyenangkan, memberi pujian ketika berhasil, memberi penguatan ketika gagal, mendampingi anak ketika belajar, sehingga anak merasa terapresiasi karena belajar. Ketersediaan waktu ibu terhadap anak dirasa memegang peranan penting, namun hal tersebut begitu sulit direalisasikan di era global seperti saat ini.

Seiring dengan perkembangan zaman dan kesetaraan gender dalam kesempatan memperoleh pendidikan, menimbulkan kesadaran diri seorang perempuan untuk mengembangkan serta mengaktualisasikan potensi dengan meniti karir melalui bekerja (Siregar, 2007). Hal ini juga mungkin dikarenakan oleh berkembangnya tatanan kehidupan, sehingga kebutuhan dalam keluarga juga semakin meningkat mengakibatkan banyak ibu saat ini yang mengambil keputusan bekerja selain berstatus sebagai ibu rumah tangga untuk menopang dan membantu ayah dalam memenuhi kebutuhan keluarga di bidang perekonomian baik pekerjaan yang dilakukan dirumah maupun di luar rumah (Hanum \& Surakarta, 2017).

Seorang ibu pekerja dapat dipastikan membagi perhatiannya untuk pekerjaan dan tentunya untuk keluarga (Wibowo \& Saidiyah, 2013). Selain itu, waktu yang dimiliki ibu pekerja juga menjadi lebih sedikit untuk keluarga terutama dalam mengasuh dan mendidik putraputrinya, dapat dipastikan juga tanggung jawab yang dimiliki seorang ibu juga kian bertambah (Nurhamida, 2013). Seorang ibu dengan status sebagai ibu pekerja dapat mempengaruhi peran maupun hubungannya dengan keluarga terutama dalam hal pengasuhan putra-putrinya, bahkan jika tidak mampu mengatur jadwal pekerjaan dengan waktu bersama keluarga dapat memicu stress dan konflik dengan anggota keluarga (Basti, 2015). Selaras juga dengan pandangan dari Slameto (2015) jika orang tua kurang memberi perhatian termasuk dalam pendidikan seperti acuh taka tau atau tidak mempedulikan pendidikan anaknya dapat berdampak terhadap kemampuan atau keberhasilan anak anak dalam pendidikan. Bagi ibu pekerja hal tersebut merupakan tantangan ketika ibu harus menjalankan peran ganda dalam waktu yang bersamaan. Seorang ibu yang memiliki pekerjaan selain mengurusi segala kepentingan rumah tangga juga harus konsisten dan disiplin dalam membagi waktunya (Akbar, 2016). Meskipun dalam kondisi lelah dengan segudang rutinitas yang dijalaninya, kewajibannya terhadap anak tetap harus dilaksanakan. Ibu pekerja harus lebih kreatif dalam mengatur waktu terutama dalam hal menumbuhkan dan menjaga motivasi belajar anak, sehingga anak tidak merasa kehilangan perhatian, dorongan maupun kasih sayang dari ibunya kendatipun waktu yang dimilikinya tidak penuh untuk selalu berada dirumah mendampingi anak terutama dalam belajar.

Saat ini jumlah ibu pekerja semakin meningkat dijumpai di berbagi sektor, namun tidak dapat dipungkiri masih terdapat ibu yang hingga saat ini tetap mengemban profesi sebagai ibu rumah tangga tanpa terikat suatu pekerjaan dengan institusi tertentu. Menjadi ibu rumah tangga memiliki begitu banyak kewajiban yang harus dilaksanakan. Meski dipandang selalu berada dirumah, tanggung jawab dan kewajiban yang diemban begitu kompleks baik itu terhadap suami maupun anaknya secara penuh. Terutama kepada anak yang masih ada dalam usia sekolah dasar, kehadiran ibu sangatlah berpengaruh besar terhadap perkembangan anak. Berstatus sebagai ibu rumah tangga, hal tersebut berarti ibu memiliki waktu penuh berada dirumah untuk keluarga terutama anak, ibu rumah tangga dapat secara penuh mengasuh, membimbing serta mendidik anak tanpa membagi perhatian dan terikat tanggung jawab pekerjaan (Junaidi, 2017). Dengan demikian, seorang ibu rumah tangga dipandang dapat lebih fokus untuk mengasuh, membimbing dan mendidik anak terutama untuk menumbuhkan semangat dan motivasi belajar bagi anak. 
Secara teoretis antara ibu pekerja dan rumah tangga tentunya memiliki perbedaan khususnya pada tanggung jawab yang diemban serta waktu dengan anak yang disinyalir menyebabkan perbedaan motivasi belajar pada diri siswa. Beberapa peneliti telah mengkaji mengenai perbedaan antara ibu pekerja dan ibu rumah tangga, salah satunya adalah hasil penelitian dari (Mardiah, 2014) menunjukkan bahwa terdapat perbedaan yang signifikan prestasi belajar anak pada ibu bekerja dan ibu tidak bekerja dengan rerata prestasi belajar anak pada ibu bekerja yaitu 73.70 kurang dari rerata prestasi belajar anak pada ibu tidak bekerja yaitu 83.95 dengan hasil $(p=0,003)$. Penelitian yang secara khusus mengkaji mengenai perbedaan motivasi belajar siswa antara ibu pekerja dan ibu rumah tangga di sekolah dasar hingga saat ini belum ditemukan. Dengan demikian perlu dibuktikan secara empiris mengenai signifikansi perbedaan motivasi belajar yang ditimbulkan dari adanya perbedaan-perbedaan antara ibu pekerja dan ibu rumah tangga. Motivasi belajar siswa timbul memang tidak semata-mata hanya dipengaruhi oleh ibu saja, namun tidak dapat dipungkiri pemberian dorongan ataupun perhatian dari ibu selaku keluarga dan orang terdekat bagi siswa sangat mempengaruhi timbulnya motivasi belajar siswa.

Berdasarkan perbedaan antara ibu pekerja dan ibu rumah tangga yang diduga menimbulkan perbedaan motivasi belajar yang dimiliki siswa serta penelitian yang dilakukan oleh (Mardiah, 2014) yang mengkaji mengenai perbedaan prestasi belajar siswa antara ibu bekerja dan tidak bekerja, maka dalam penelitian ini peneliti mengkaji tentang perbedaan motivasi belajar siswa yang diduga disebabkan oleh adanya pernbedaan antara ibu pekerja dan ibu rumah tangga dikarenakan seorang siswa yang mencapai prestasi belajar yang memuaskan diawali oleh motivasi belajar yang dimilikinya, meski kedua hal tersebut dipandang berbeda, namun perlu dibuktikan secara empiris mengenai kebenarannya. Tujuan penelitian ini adalah untuk menentukan perbedaan yang signifikan motivasi belajar siswa kelas IV antara ibu pekerja dan ibu rumah tangga

\section{Metode}

Penelitian ini dilakukan di SD Gugus Kompyang Sujana Denpasar Utama Tahun Ajaran 2019/2020 menggunakan rancangan "ex post facto". Ex post facto mengindikasikan bahwa perubahan-perubahan pada variabel bebas telah terjadi ketika berlangsungnya penelitian terhadap variabel terikat (Sappaile, 2010). Jenis penelitian ex post facto yang digunakan adalah kausal komparatif atau hubungan sebab akibat. Penelitian kausal komparatif diartikan sebagai kegiatan penelitian yang dilakukan dengan tujuan mengidentifikasi hubungan antar sebab akibat dan berusaha kembali mencari hubungan sebab akibat tersebut dalam hubungan suatu variabel kemudian dibedakan variabel bebas serta variabel terikatnya (Sukardi, 2012).

Bila digambarkan, maka penelitian kausal komparatif bisa diamati pada gambar 1:

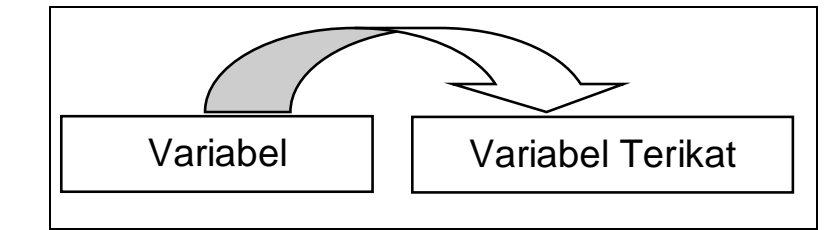

Gambar 1. Gambaran Penelitian Kausal Komparatif

(Sukardi, 2012:172) 
Berdasarkan gambar tersebut, variabel bebas yang dilambangkan dengan huruf $\mathrm{X}$ adalah status pekerjaan ibu dalam keluarga, yang digolongkan ke dalam kelompok siswa ibu pekerja dan kelompok siswa ibu rumah tangga, sedangkan variabel terikat yang dilambangan dengan huruf $Y$ adalah motivasi belajar.

Populasi dalam penelitian ini adalah seluruh siswa kelas IV SD Gugus Kompyang Sujana Denpasar Utara Tahun Ajaran 2019/2020 yang terdiri atas 8 sekolah dengan jumlah siswa keseluruhan yaitu 392 orang. Setelah mengetahui populasi dalam penelitian, yang dilakukan selanjutnya menentukan sampel penelitian. Dalam penelitian digunakan teknik non probability sampling yang merupakan cara yang dipergunakan dalam penentuan sampel dengan tidak memberikan peluang bagi seluruh anggota dalam populasi untuk menjadi sampel dalam penelitian (Sugiyono, 2018). Purposive sampling merupakan model non probability sampling yang dipergunakan. Purposive sampling ialah cara dalam menentukan sampel mengacu pada ciri atau tujuan tertentu yang ditetapkan peneliti (Dantes, 2012). Penentuan sampel dengan purposive sampling dalam penelitian ini dikarenakan peneliti memiliki tujuan tertentu atau pertimbangan terhadap sampel. Adapun kriteria atau pertimbangan yang ditetapkan penelitian ini sebagai berikut: 1) Siswa dengan status pekerjaan ibu dalam keluarga sebagai ibu pekerja a) pendidikan terakhir ibu SMA/sederajat, b) memiliki atau terikat pekerjaan di luar rumah untuk memperoleh penghasilan, c) intensitas waktu ibu bekerja di luar rumah dengan rentang waktu antara 8-10 jam per hari. 2) Siswa dengan status pekerjaan ibu dalam keluarga sebagai ibu rumah tangga a) pendidikan terakhir ibu SMA/sederajat, b) tidak memiliki atau terikat pekerjaan selain sebagai ibu rumah tangga. Berdasarkan kriteria atau pertimbangan yang telah ditetapkan dalam penelitian ini, sampel yang berasal dari siswa dengan status ibu dalam keluarga sebagai ibu pekerja sebanyak 74 siswa dan siswa dengan status ibu dalam keluarga sebagai ibu rumah tangga sebanyak 74 siswa.

Metode non tes diterapkan untuk mengumpulkan data mengenai motivasi belajar. Metode non tes ialah cara yang dirancang untuk mengumpulkan data yang umumnya tidak bersifat menguji melainkan memahami karakteristik subjek yang diteliti (Marhaeni, 2012). Metode non tes yang digunakan ialah angket. Angket merupakan teknik yang digunakan untuk mengumpulkan data yang dilakukan dengan cara memberi pertanyaan atau pernyataan tertulis untuk dijawab oleh responden (Sugiyono, 2018). Bentuk angket yang digunakan ialah angket tertutup dengan menyediakan pernyataan tertutup yang memiliki batasan terhadap respon dari responden (Agung, 2014). Motivasi belajar pada penelitian ini diukur berdasarkan indicator dari Uno (2019) yang diklasifikasikan sebagai berikut: 1) Adanya hasrat dan keinginan berhasil, 2) Adanya dorongan dan kebutuhan dalam belajar, 3) Adanya harapan dan cita-cita masa depan, 4) Adanya penghargaan dalam belajar, 5) Adanya kegiatan yang menarik dalam belajar, 6) Adanya lingkungan belajar yang kondusif. Instrumen yang digunakan mengukur motivasi belajar adalah angket. Kisi-kisi angket motivasi belajar diuraikan pada tabel 1.

Tabel 1. Kisi-Kisi Angket Motivasi Belajar

\begin{tabular}{llccc}
\hline \multicolumn{1}{c}{ Variabel } & \multicolumn{1}{c}{ Indikator } & Jumlah & \multicolumn{2}{c}{ No ltem } \\
\cline { 4 - 5 } \cline { 4 - 5 } $\begin{array}{l}\text { Motivasi } \\
\text { Belajar }\end{array}$ & $\begin{array}{l}\text { Adanya hasrat dan keinginan } \\
\text { berhasil }\end{array}$ & 6 & $1,3,5$ & Positif \\
\cline { 2 - 5 } & $\begin{array}{l}\text { Adanya dorongan dan } \\
\text { kebutuhan dalam belajar }\end{array}$ & 3 & 8 & $14,17,24$ \\
\hline
\end{tabular}




\begin{tabular}{llll}
\hline & 5 & $2,20,33$ & 9,23 \\
\cline { 2 - 4 } $\begin{array}{l}\text { Adanya harapan dan cita-cita } \\
\text { masa depan }\end{array}$ & 5 & $4,26,30,32$ & 22 \\
$\begin{array}{l}\text { Adanya penghargaan dalam } \\
\text { belajar }\end{array}$ & 7 & $\begin{array}{l}6,10,13,18, \\
29\end{array}$ & 7,11 \\
\hline $\begin{array}{l}\text { Adanya kegiatan yang menarik } \\
\text { dalam belajar }\end{array}$ & 7 & $\begin{array}{l}16,19,25, \\
27,31\end{array}$ & 15,21 \\
\hline $\begin{array}{l}\text { Adanya lingkungan belajar } \\
\text { yang kondusif }\end{array}$ & 33 & 21 & 12 \\
\hline Jumlah & & & \\
\hline
\end{tabular}

Skala data atau standar pengukuran motivasi belajar mengacu pada skala Likert yang termodifikasi empat skala. Jawaban setiap butir pernyataan merujuk pada pedoman yang ditetapkan skala Likert empat skala dengan alternatif pilihan jawaban yaitu sangat setuju (SS), setuju (S), tidak setuju (TS), sangat tidak setuju (STS). Data yang diperoleh dalam penelitian ini berupa data dengan skala interval. Skala data atau standar pengukuran motivasi belajar menggunakan skala Likert yang telah dimodifikasi empat skala dimaksudkan untuk menghilangkan kelemahan yang terkandung oleh skala lima tingkat. Empat alternatif jawaban yang telah dimodifiksi dari skala lima tingkat Likert yaitu "sangat setuju (SS), setuju (S), tidak setuju (TS) dan sangat tidak setuju (STS)" (Sukardi, 2012:146).

Sebelum angket digunakan sebagai instrumen pengumpulan data, maka terlebih dahulu diuji kelayakan instrumen yang digunakan untuk mengukur motivasi belajar siswa dengan melakukan validasi instrumen yang meliputi validasi teoretis dan validasi empiris. Validasi teoretis yang dilakukan dalam penelitian ini adalah validitas konstruk (construct validity) yang merupakan suatu kodisi yang dapat menunjukkan sebuah instrumen yang disusun atau dikonstruksi dapat mengukur aspek-aspek berpikir sesuai yang termuat dalam tujuan pembelajaran (Suharsimi Arikunto, 2016). Untuk menguji validitas konstruk instrumen yang digunakan untuk mengumpulan data dikonsultasikan dengan pembimbing tentang instrumen yang disusun berdasarkan teori mengenai kelayakan instrumen tersebut. Sedangkan, uji empiris meliputi validitas butir dan reliabilitas. Instrumen yang baik harus memenuhi dua persyaratan yaitu valid dan reliabel. Berdasarkan hasil uji validitas butir angket motivasi belajar sebanyak 40 butir angket yang diujikan terhadap 50 responden menggunakan rumus Korelasi Product Moment, diperoleh hasil 33 butir angket yang valid dan 7 butir angket yang tidak valid atau drop dan berdasarkan hasil uji reliabilitas menggunakan rumus Alpha Cronbach, reliabilitas angket motivasi belajar berada pada kriteria sangat tinggi dengan koefisien korelasi yaitu 0,85.

Data motivasi belajar yang diperoleh, kemudian dianalisis. Analisis yang digunakan pada penelitian ini adalah analisis statistik dikarenakan data yang diperoleh dalam penelitan ini berupa angka atau bersifat kuantitatif. Metode analisis statistik yang digunakan untuk mengolah data yang telah diperoleh adalah analisis statistik inferensial. Statistik inferensial adalah teknik statistik yang digunakan untuk menganalisis data sampel dan hasil analisis data tersebut diberlakukan untuk populasi (Sugiyono, 2018). Teknik analisis statistik inferensial yang digunakan yaitu uji-t untuk penelitian empiris $\left(\mathrm{n}_{1}=\mathrm{n}_{2}\right)$. Adapun kriteria pengujian yaitu pada taraf signifikansi $5 \%$, dengan $d k=n 1+n 2-2$. Jika harga $t_{\text {hitung }} \leq t_{\text {tabel, }}$, maka $H_{0}$ diterima, sedangkan jika harga thitung $>$ tabel, maka $\mathrm{H}_{0}$ ditolak.

Sebelum uji-t digunakan sebagai teknik analisis data dalam penelitian ini, dilakukan uji prasyarat yang harus dipenuhi yaitu uji normalitas sebaran data di tiap kelompok dan uji homogenitas varian antar kelompok. Uji normalitas sebaran data yang digunakan dalam 
penelitian ini adalah Uji Kolmogorov-Smirnov dengan kriteria pengujian adalah apabila nilai maksimum $\leq$ nilai tabel Kolmogorov-Smirnov, maka data berdistribusi normal. Sebaliknya jika nilai maksimum > nilai tabel Kolmogorov-Smirnov, maka data tidak berdistribusi normal. Uji homogenitas dalam penelitian ini menggunakan uji-F dengan kriteria pengujian jika nilai $F_{\text {hitung }} \leq$ nilai $F_{\text {tabel. }}$ Sedangkan jika $F_{\text {hitung }}>F_{\text {tabel, }}$ maka sampel dinyatakan tidak homogen. Pengujian dilakukan pada taraf signifikan $5 \%$ dengan derajat kebebasan untuk pembilang $\mathrm{n} 1-1$ dan derajat kebebasan untuk penyebut n2-1. Adapun hipotesis yang diuji dalam penelitian ini menggunakan uji-t untuk penelitian empiris $\left(\mathrm{n}_{1}=\mathrm{n}_{2}\right)$ adalah hipotesis nol $\left(\mathrm{H}_{0}\right)$ yang berbunyi "Tidak terdapat perbedaan yang signifikan motivasi belajar siswa kelas IV antara ibu pekerja dan ibu rumah tangga di SD Gugus Kompyang Sujana Denpasar Utara Tahun Ajaran 2019/2020”.

\section{Hasil dan Pembahasan}

Data yang diperoleh dalam penelitian ini adalah data motivasi belajar siswa kelas IV di SD Gugus Kompyang Sujana Denpasar Utara Tahun Ajaran 2019/2020. Data mengenai motivasi belajar siswa kelas IV kelompok ibu pekerja diperoleh melalui penyebaran angket sebanyak 33 butir pernyataan terhadap 74 siswa atau responden dan terdapat empat pilihan jawaban untuk setiap butir pernyataan, diperoleh skor maksimum yaitu 127 dan skor minimum yaitu 80 . Berdasarkan perhitungan distribusi frekuensi relatif, diperoleh hasil sebagaimana disajikan pada tabel 2.

Tabel 2. Distribusi Frekuensi Relatif Motivasi Belajar Siswa Kelas IV Kelompok Ibu Pekerja

\begin{tabular}{ccccc}
\hline Interval Nilai & Nilai Tengah $\left(\mathrm{x}_{\mathrm{i}}\right)$ & $\mathrm{f}_{\mathrm{i}}$ & $\mathrm{f}_{\mathrm{i}} \mathrm{x}_{\mathrm{i}}$ & $\mathrm{f}_{\mathrm{i}}$ Relatif $(\%)$ \\
\hline $80-85$ & 82,5 & 6 & 496 & 8,11 \\
\hline $86-91$ & 88,5 & 3 & 265,5 & 4,05 \\
\hline $92-97$ & 94,5 & 5 & 472,5 & 6,76 \\
\hline $98-103$ & 100,5 & 11 & 1105,5 & 14,86 \\
\hline $104-109$ & 106,5 & 17 & 1810,5 & 22,97 \\
\hline $110-115$ & 112,5 & 17 & 1912,5 & 22,97 \\
\hline $116-121$ & 118,5 & 4 & 474 & 5,41 \\
\hline $122-127$ & 124,5 & 11 & 1369,5 & 14,86 \\
\hline & Jumlah & 74 & 7906 & 100 \\
\hline
\end{tabular}

Berdasarkan kategori Skala Lima Teoretik, rata-rata motivasi belajar siswa kelompok ibu pekerja adalah 107,26, berada pada rentang 107,25 - 132 dan termasuk pada kategori sangat baik.

Selanjutnya, data mengenai motivasi belajar siswa kelas IV kelompok ibu rumah tangga diperoleh melalui penyebaran angket sebanyak 33 butir pernyataan terhadap 74 siswa atau responden dan terdapat empat pilihan jawaban untuk setiap butir pernyataanskor maksimum siswa yaitu 121 dan skor minimum siswa yaitu 78. Berdasarkan perhitungan distribusi frekuensi relatif, diperoleh hasil sebagaimana disajikan pada tabel 3.

Tabel 3. Distribusi Frekuensi Relatif Motivasi Belajar Siswa Kelas IV Kelompok Ibu Rumah Tangga

\begin{tabular}{ccccc}
\hline Interval Nilai & Nilai Tengah $\left(\mathrm{x}_{\mathrm{i}}\right)$ & $\mathrm{f}_{\mathrm{i}}$ & $\mathrm{f}_{\mathrm{i}} \mathrm{x}_{\mathrm{i}}$ & $\mathrm{f}_{\mathrm{i}}$ Relatif $(\%)$ \\
\hline $78-83$ & 80,5 & 16 & 1288 & 21,62 \\
\hline $84-89$ & 86,5 & 6 & 519 & 8,11 \\
\hline $90-95$ & 92,5 & 11 & 1017,5 & 14,86 \\
\hline
\end{tabular}


Jurnal Mimbar IImu, Vol. 25 No. 2, 2020

P-ISSN: 1829-877X E-ISSN : 2685-9033

\begin{tabular}{ccccc}
\hline $96-101$ & 98,5 & 9 & 886,5 & 12,16 \\
\hline $102-107$ & 104,5 & 9 & 940,5 & 12,16 \\
\hline $108-113$ & 110,5 & 10 & 1105 & 13,51 \\
\hline $114-119$ & 116,5 & 11 & 1281,5 & 14,86 \\
\hline $120-125$ & 122,5 & 2 & 245 & 2,70 \\
\hline
\end{tabular}

Berdasarkan kategori Skala Lima Teoretik, rata-rata motivasi belajar siswa kelompok ibu rumah tangga adalah 98,12, berada pada rentang 90,75 - 107,25 dan termasuk dalam kategori baik.

Penelitian ini mengaplikasikan uji t untuk penelitian empiris $\left(n_{1}=n_{2}\right)$ untuk menguji hipotesis penelitian. Sebelum dilakukannya pengujian hipotesis, terlebih dahulu dilakukan uji prasyarat analisis data yang meliputi uji normalitas sebaran data dan uji homogenitas varian. Uji normalitas dimaksudkan untuk mengetahui sebaran data motivasi belajar siswa kelompok ibu pekerja dan motivasi belajar siswa kelompok ibu rumah tangga berdistribusi normal atau tidak sehingga dapat menentukan teknik analisis data yang akan digunakan.

Uji normalitas dalam penelitian ini menggunakan Uji Kolmogorov-Smirnov. Dikarenakan jumlah sampel lebih dari 40, maka digunakan rumus untuk menentukan Ks tabel. Rumus yang digunakan untuk menentukan Kolmogorov-Smirnov tabel adalah $\frac{1,36}{\sqrt{N}}$, sehingga diperoleh Kolmogorov-Smirnov tabel yaitu 0,158 pada taraf signifikasi $5 \%$. Berdasarkan hasil uji normalitas data, didapatkan hasil perhitungan uji normalitas dengan menggunakan rumus Kolmogorov-Smirnov, disajikan dalam tabel 4.

Tabel 4. Rekapitulasi Hasil Uji Normalitas Data Motivasi Belajar Siswa Kelompok Ibu Pekerja dan Motivasi Belajar Siswa Kelompok lbu Rumah Tangga

\begin{tabular}{cccc}
\hline Sampel & $\begin{array}{c}\text { Nilai Maksimum } \\
\left|\mathrm{F}_{\mathrm{T}}-\mathrm{F}_{\mathrm{S}}\right|\end{array}$ & $\begin{array}{c}\text { Nilai Tabel } \\
\text { Kolmogorov } \\
\text { Smirnov }\end{array}$ & Keterangan \\
\hline $\begin{array}{c}\text { Kelompok ibu } \\
\text { pekerja }\end{array}$ & 0,071 & & Berdistribusi Normal \\
\hline $\begin{array}{c}\text { Kelompok ibu } \\
\text { rumah tangga }\end{array}$ & 0,117 & 0,158 & Berdistribusi Normal \\
\hline
\end{tabular}

Merujuk pada tabel tersebut, dapat diketahui hasil uji normalitas data motivasi belajar siswa kelas IV baik kelompok ibu pekerja maupun kelompok ibu rumah tangga di SD Gugus Kompyang Sujana Denpasar Utara dengan membandingkan nilai maksimum $\left|F_{T}-F_{S}\right|$ dengan nilai tabel Kolmogorov - Smirnov. Diketahui nilai maksimum $\left|\mathrm{F}_{\mathrm{T}}-\mathrm{F}_{\mathrm{S}}\right|$ dari data motivasi belajar siswa kelompok ibu pekerja $=0,071<$ nilai tabel Kolmogorov-Smirnov $=0,158$ yang berarti sebaran data motivasi belajar siswa kelompok ibu pekerja berdistribusi normal. Nilai maksimum $\left|F_{\mathrm{T}}-\mathrm{F}_{\mathrm{S}}\right|$ dari data motivasi belajar siswa kelompok ibu rumah tangga $=0,117<$ nilai tabel Kolmogorov-Smirnov = 0,158 yang berarti sebaran data motivasi belajar siswa kelompok ibu rumah tangga berdistribusi normal.

Selanjutnya dilakukan uji homogenitas varian antar kelompok yang dimaksudkan untuk meyakinkan adanya perbedaan merupakan akibat dari perbedaan yang dimiliki antar kelompok dan bukan karena dalam kelompok tersebut terdapat perbedaan menggunakan uji $\mathrm{F}$ pada taraf signifikansi $5 \%$ dengan $\mathrm{dk}$ pembilang $\mathrm{n} 1-1$ dan $\mathrm{dk}$ penyebut $\mathrm{n} 2-2$, didapatkan hasil perhitungan uji homogenitas varian dengan uji $\mathrm{F}$ disajikan pada tabel 5. 
Jurnal Mimbar Ilmu, Vol. 25 No. 2, 2020

P-ISSN: 1829-877X E-ISSN : 2685-9033

Tabel 5. Rekapitulasi Hasil Uji Homogenitas Varian Data Motivasi Belajar

\begin{tabular}{|c|c|c|c|c|c|}
\hline Sampel & Varian & $F_{\text {hitung }}$ & Dk & $\mathrm{F}_{\text {tabel }}$ & Keterangan \\
\hline $\begin{array}{l}\text { Kelompok ibu } \\
\text { pekerja }\end{array}$ & 145,15 & & $74-1=73$ & & \\
\hline $\begin{array}{l}\text { Kelompok ibu } \\
\text { rumah } \\
\text { tangga }\end{array}$ & 176,00 & 1,21 & $74-1=73$ & 1,47 & Homogen \\
\hline
\end{tabular}

Berdasarkan tabel tersebut, dapat diketahui nilai $F_{\text {hitung }}=1,21$ dan nilai $F_{\text {tabel }}=1,47$ pada taraf signifikansi $5 \%$ dengan dk pembilang $=73$ dan $\mathrm{dk}$ penyebut $=73$. $\mathrm{F}_{\text {hitung }}=1,21<\mathrm{F}_{\text {tabel }}=$ 1,47. Dengan demikian berarti data motivasi belajar siswa kelompok ibu pekerja dan motivasi belajar siswa kelompok ibu rumah taangga memiliki varian yang homogen.

Didasari atas uji prasyarat yang telah dilakukan, diketahui sebaran kedua kelompok berdistribusi normal dan memiliki varian yang homogen, sehingga pengujian hipotesis menggunakan uji-t untuk penelitian empiris $\left(n_{1}=n_{2}\right)$ dapat dilakukan. Adapun hasil pengujian hipotesis, disajikan pada tabel 6.

Tabel 6. Rekapitulasi Hasil Pengujian Hipotesis dengan Uji-t

\begin{tabular}{ccccccccc}
\hline $\begin{array}{c}\text { Kelompok } \\
\text { Sampel }\end{array}$ & Rerata & $S E M^{2}$ & $S E_{M d}$ & $\mathrm{~N}$ & $\mathrm{Dk}$ & $\mathrm{t}_{\text {hitung }}$ & $\mathrm{t}_{\text {tabel }}$ & Keterangan \\
\hline $\begin{array}{c}\text { Ibu } \\
\text { Pekerja }\end{array}$ & 107,26 & 1,99 & & 74 & & & & $\mathrm{H}_{0}$ ditolak \\
$\begin{array}{c}\text { Ibu } \\
\text { Rumah } \\
\text { Tangga }\end{array}$ & 98,12 & 2,41 & 2,10 & 74 & 146 & 4,352 & 1,976 & \\
\end{tabular}

Berdasarkan tabel tersebut, dapat diketahui harga $t_{\text {hitung }}=4,352$ dan pada taraf signifiansi $5 \%$ dengan derajat kebebasan $(\mathrm{dk}=74+74-2)=146$ diperoleh $t_{\text {tabel }}=1,976$. Hal ini berarti $t_{\text {hitung }}=4,352>t_{\text {tabel }}=1,976$. Jadi, dapat disimpulkan bahwa $\mathrm{H}_{0}$ ditolak (gagal diterima), hal ini berarti terdapat perbedaan yang signifikan motivasi belajar siswa kelas IV antara ibu pekerja dan ibu rumah tangga di SD Gugus Kompyang Sujana Denpasar Utara Tahun Ajaran 2019/2020.

Perolehan hasil perhitungan analisis data yang dilakukan, menunjukkan bahwa rata-rata motivasi belajar siswa kelompok ibu pekerja adalah 107,26 lebih dari motivasi belajar siswa kelompok ibu rumah tangga yaitu sebesar 98,12. Oleh sebab itu, dalam penelitian ini telah dibuktikan secara empiris bahwa terdapat perbedaan motivasi belajar siswa antara ibu pekerja dan ibu rumah tangga, serta motivasi belajar siswa kelompok ibu pekerja dikategorikan sangat baik sedangkan motivasi belajar siswa kelompok ibu rumah tangga dikategorikan baik.

Perbedaan motivasi belajar siswa tersebut disebabkan oleh adanya perbedaan antara ibu pekerja dan ibu rumah tangga yang signifikan dengan pembuktian secara empiris bahwa siswa yang ibunya bekerja memiliki motivasi lebih dari siswa yang ibunya sebagai ibu rumah tangga. Hal ini membuktikan ibu pekerja dapat menjalankan peran gandanya dengan baik tanpa mengabaikan tanggung jawabnya sebagai ibu terutama kepada anak yang masih pada usia sekolah. Seorang ibu yang berstatus sebagai ibu pekerja memiliki banyak kelebihan-kelebihan yang membuatnya lebih ungul dalam beberapa bidang dibandingkan seorang ibu dengan status hanya sebagai ibu rumah tangga. Hal ini selaras dengan pandangan dari (Basti, 2015) bahwa terdapat delapan dampak positif ibu yang bekerja. Salah satu dampak positifnya ialah ibu memiliki pengalaman dan wawasan yang lebih luas sehingga intelektualitas ibu akan terus 
berkembang. Hal ini menimbulkan pola pikir ibu yang kian luas dan berkembang karena adanya sosialisasi atau diskusi dengan teman sejawat, misalnya seperti pola asuh terhadap anak, cara memotivasi anak dalam belajar maupun cara mengatasi permasalah pada anak. Selain itu, ibu juga lebih mengerti mengenai perkembangan zaman saat ini, entah itu mengambil dampak positif ataupun menanggulangi dampak negatifnya khususnya pada anak yang masih dalam usia sekolah. kelebihan lainnya ialah secara tidak langsung ibu akan menjadi model atau panutan bagi anak dalam ketekunannya, semangt, kerja keras dan sifat pantang menyerah, seperti halnya setelah Lelah karena seharian bekerja, ketika dirumah ibu tidak lalai terhadap tanggung jawabnya yakni sebagai seorang ibu. Kelebihan-kelebihan tersebutlah yang mendukung sehingga motivasi belajar siswa kelompok ibu pekerja lebih dari motivasi belajar siswa kelompok ibu rumah tangga. Kendatipun tidak memiliki waktu penuh untuk berada dirumah, dengan memiliki pandangan yang lebih luas ibu menjadi mengerti bagaimana kiat-kiat yang baik sehingga dapat menumbuhkan motivasi belajar anak. Sedangkan, siswa dengan status pekerjaan ibu sebagai ibu rumah tangga dalam temuan ini diketahui memiliki motivasi yang lebih rendah, yang disinyalir berdampak dari cara atau pola asuh ibunya yang sebagai ibu rumah tangga. Mengacu pada pekerjaan ibu yaitu ibu rumah tangga dipastikan pekerjaan ibu hanya mengurusi urusan rumah tangga, memasak, mencuci pakaian, membersihkan rumah dan sebagainya. Hal tersebut tidak menutup kemungkinan bahwa ibu kurang mendapatkan ruang untuk mengaktualisasikan potensi yang dimilikinya serta jaringan social yang dimiliki oleh seorang ibu rumah tangga tidak seluas ibu pekerja. Pengalaman ibu rumah tangga juga lebih minim dibandingkan ibu pekerja. Hal-hal tersebutlah yang berdampak signifikan terhadap motivasi belajar anak.

Temuan hasil penelitian ini berkaitan dengan teori yang menyatakan bahwa motivasi belajar ialah dorongan yang berpangkal dalam diri siswa sendiri, namun timbulnya motivasi belajar yang memungkinkan terjadinya aktivitas belajar sehingga mencapai harapan yang dikehendaki baik oleh siswa itu sendiri, guru bahkan orang tua, tidak dapat hanya di dukung oleh faktor internal siswa namun juga faktor eksternal siswa juga turut memberikan andil yang besar untuk mendorong munculnya suatu motivasi belajar siswa salah satunya ialah keluarga terutama orang tua khususnya ibu sebagai orang terdekat yang berada di lingkungan siswa yang sepatutnya turut serta dan berperan penting dalam menumbuhkan motivasi belajar.

Berlandaskan pada hasil penelitian, dapat diulas implikasi bahwa seorang anak yang memiliki motivasi belajar dapat tercermin dari dalam dirinya seperti memiliki keinginan atau hasrat dalam dirinya untuk berhasil mencapai tujuan yang diinginkannya, memiliki dorongan dan kebutuhan untuk belajar dengan berpadangan bahwa belajar ialah suatu kebutuhan bukan semata kewajiban, adanya dorongan kuat seperti cita-cita untuk diraihnya sehingga keinginan atau dorongan untuk belajar lebih tinggi. Selain itu, anak juga memerlukan penghargaan ketika belajar, seperti halnya pujian ketika berhasil ataupun penguatan ketika gagal terutama dari orang-orang terdekatnya dalam hal ini khususnya adalah ibunya sebagai pendorong timbulnya motivasi belajar, kegiatan pembelajaran yang menyenangkan dan menarik perhatian artinya kegiatan yang menarik akan membuat belajar sebagai aktivitas yang menyenangkan dan bermakna, lingkungan belajar yang kondusif, artinya lingkungan yang memadai sangat diperlukan dan mendukung dalam melakukan aktivitas belajar belajar seperti kenyamanan, sarana prasarana maupun keadaan lingkungan sebagai penunjang terjadinya kegiatan belajar. Lingkungan belajar yang kondusif ini dapat diciptakan oleh guru, orang tua maupun diri siswa sendiri. Jadi, siswa yang memiliki motivasi tinggi dalam belajar memungkinkan memperoleh hasil maupun prestasi belajar yang tinggi pula, artinya semakin tinggi motivasi belajar, semakin tinggi intensitas usaha beserta upaya yang dilakukan, semakin tinggi hasil belajar yang diperolehnya, begitu juga sebaliknya (Hamdu \& Agustina, 2011).

Hasil penelitian ini relevan dengan penelitian oleh (Yuliana, 2012) menunjukkan hasil penelitian pada taraf signifikansi $5 \%$ diperoleh $t_{\text {hitung }}=3,63>t_{\text {tabel }}=2,00$ maupun pada taraf 
signifikansi $1 \% t_{\text {tabel }}=2,66$. Mengacu pada rumusan hipotesis maka terdapat perbedaan ratarata hasil prestasi belajar siswa yang ibunya bekerja dengan rata-rata hasil belajar siswa ibu tidak bekerja. Berdasarkan hasil analisis data diperoleh persentase perbandingan nilai prestasi belajar siswa yang ibunya bekerja yaitu $82,35 \%$ lebih dari nilai prestasi belajar yang ibunya tidak bekerja yaitu 44,12\%. Meskipun variabel terikat pada penelitian terdahulu mengkaji mengenai prestasi belajar, sedangkan variabel terikat pada penelitian ini mengkaji mengenai motivasi belajar, pada dasarnya tercapainya prestasi yang baik dalam belajar tidak lepas dari motivasi belajar yang dimilikinya. Serta relevan dengan hasil penelitian oleh Ifrotul Evyndacari pada tahun 2017 menunjukkan terdapat perbedaan yang signifikan kemandirian perilaku remaja antara ibu berkarir dan ibu rumah tangga. Terdapat perbedaan rata-rata kemandirian perilaku remaja ibu berkarir yaitu 67,422 lebih dari kemandirian remaja ibu rumah tangga yaitu 45,387.

\section{Simpulan}

Dengan diperolehnya hasil penelitian serta pembahasan, dapat diketahui bahwa terdapat perbedaan yang signifikan motivasi belajar siswa kelas IV antara ibu pekerja dan ibu rumah tangga dengan rata-rata motivasi belajar siswa kelompok ibu pekerja adalah 107,26 lebih dari motivasi belajar siswa kelompok ibu rumah tangga yaitu sebesar 98,12 , serta dari hasil analisis data menggunakan uji-t untuk penelitian empiris $\left(n_{1}=n_{2}\right)$ diperoleh $t_{\text {hitung }}=4,352>t_{\text {tabel }}=1,976$ maka $\mathrm{H}_{0}$ ditolak. Berdasarkan hal tersebut berarti terdapat perbedaan yang signifikan motivasi belajar siswa kelas IV antara ibu pekerja dan ibu rumah tangga di SD Gugus Kompyang Sujana Denpasar Utara Tahun Ajaran 2019/2020. Sebagai tindak lanjut dari hasil penelitian ini, adapun saran yang dapat diberikan kepada: 1) Guru, disarankan agar guru kreatif dalam merancang pembelajaran, memilih metode yang efektif, menentukan media yang tepat maupun menumbuhkan kedekatan dengan siswa. 2) Kepala Sekolah, disarankan agar senantiasa melakukan monitoring keberlangsungan kegiatan pembelajaran disekolah serta turut mengoptimalkan motivasi belajar siswa dengan mengambil kebijakan-kebiajak seperti menyusun program yang dapat menstimulus timbulkan motivasi belajar dan mengupayakan fasilitas yang dimiliki sekolah. 3) Orang Tua, khususnya ibu disarankan agar senantiasa memperhatikan dan terlibat langsung dalam proses pembelajaran anak ketika berada dirumah, membantu mengarahkan anak pada hal-hal yang bermanfaat bagi dirinya dalam menggapi harapan dan cita-citanya serta tetap melakukan kontrol. 4) Peneliti Lain, disaran agar menindaklanjuti penelitian ini dengan mengkaji penelitian terkait dengan pola asuh yang digunakan orang tua khususnya ibu pekerja dan ibu rumah tangga dalam menumbuhkan motivasi belajar siswa.

\section{Daftar Pustaka}

Agung, A. A. G. (2014). Metodelogi Penelitian Pendidikan. Adistiya Media Publishing.

Akbar, Z., Kartika, K., Psikologi, F. P., Jakarta, U. N., Psikologi, F. P., \& Jakarta, U. N. (2016). Konflik Peran Ganda dan Keberfungsian Keluarga Pada Ibu Yang Bekerja. 5(2001).

Apreviadizy, P. (2014). Perbedaan Stres Ditinjau dari Ibu bekerja dan Ibu Tidak Bekerja. 9(1), 58-65.

Arikunto, Suharsimi. 2016. Dasar-Dasar Evaluasi Pendidikan. Jakarta: PT Bumi Aksara.

Astriyani, T. I. H. (2018). Hubungan Motivasi Belajar dan Tindakan Guru dengan Prestasi Belajar Siswa. 3(6), 806-809.

Basti, E. M. P. D. (2015). Pengasuhan Ibu Berkarir Dan Internalisasi Nilai Karir Pada Remaja. 03(01), 165-183. 
Dantes, Nyoman. 2012. Metode Penelitian. Yogyakarta: Penerbit Andi.

Darmawati, J. (2013). Pengaruh Motivasi Belajar dan Gaya Belajar Terhadap Prestasi Belajar Ekonomi Siswa Sma Negeri di Kota Tuban. 1(1), 79-90.

Emda, A. (2017). Kedudukan Motivasi Belajar Siswa dalam Pembelajaran. 5(2).

Evyndacari, I. Perbedaan Kemandirian Perilaku Remaja Ditinjau dari lbu Berkarir dan Ibu Rumah Tangga, 2017.

Fauziah, A., Rosnaningsih, A., Azhar, S., Studi, P., Guru, P., Dasar, S., \& Tangerang, U. M. (2017). Hubungan Antara Motivasi Belajar Dengan Minat Belajar Siswa Kelas Iv Sdn Poris Gaga 05 Kota. 4(1).

Hamdu, G., \& Agustina, L. (2011). Pengaruh Motivasi Belajar Siswa Terhadap Prestasi Belajar IPA Di Sekolah Dasar. 12(1), 90-96.

Hanum, S. L., \& Surakarta, I. (2017). Peran Ibu Rumah Tangga dalam Membangun Kesejahteraan Keluarga. 1(2).

Hidayati, F., Veronika, D., \& Kaloeti, S. (2002). Peran Ayah dalam Pengasuhan Anak.

Junaidi, H. (2017). Ibu Rumah Tangga : Streotype Perempuan Pengangguran. 12, 77-88.

Mardiah, N. (2014). Perbedaan Prestasi Belajar Anak Pada Ibu Bekerja dan Ibu Tidak Bekerja Di SDIT Adzakia Padang Tahun 2014. 35(April), 2013-2014.

Marhaeni, A. A. I. N. 2012. Pengantar Evaluasi Pendidikan. Singaraja: Universitas Pendidikan Ganesha.

Muhajis, D. D. A. N. (2018). Analisis Hubungan Antara Motivasi Belajar dengan Hasil Belajar Siswa pada Sekolah Dasar Negeri 3 Allakuang Kecamatan Maritengngae Kabupaten Sidenreng Rappang. II(2), 216-228.

Nurhamida, Y. (2013). Power In Marriage Pada Ibu Bekerja Dan Ibu Rumah Tangga. 1(2), 185198.

Oktiani, I. (2017). Kreativitas Guru dalam Memotivasi Belajar Peserta Didik. 5(2), 216-232.

Purbasari, D., \& Putri, K. (n.d.). Pembagian Peran Dalam Rumah Tangga. 16(1), 72-85.

Qmar, S. (2017). Penanggungjawab Pendidikan. I(1), 143-151.

Riswanto, A., Java, W., \& Entrepreneurs, S. (2017). Learning Motivation and Student Achievement: Description Analysis and Relationships Both Learning Motivation And Student Achievement: Description Analysis and Relationships Both. March. https://doi.org/10.23916/002017026010

Sappaile, B. I. (2010). Konsep Penelitian Ex-Post Facto. 1, 105-113.

Siregar, M. (2007). Keterlibatan Ibu Bekerja dalam Perkembangan Pendidikan Anak Mastauli Siregar. II(1), 8-18.

Slameto. 2015. Belajar dan Faktor-Faktor yang Mempengaruhinya. Jakarta: Rineka Cipta

Sugiyono. 2018. Metode Penelitian Pendidikan Pendekatan Kuantitatif, Kualitatif dan R\&D. Bandung: Alfabeta.

Sukardi. 2012. Metodologi Penelitian Pendidikan. Jakarta: PT Bumi Aksara.

Suprihatin, S. (2015). Upaya Guru dalam Meningkatkan Motivasi Belajar Siswa. 3(1), 73-82. 
Tarbiyah, J. (2017). Hakikat Pendidikan Islam: Telaah antara Hubungan Pendidikan Informal, Non Formal dan Formal. XXIV(1).

Uno, B. Hamzah. 2019. Teori Motivasi dan Pengukurannya. Jakarta: PT Bumi Aksara.

Wibowo, A., \& Saidiyah, S. (n.d.). Proses Pengasuhan Ibu Bekerja. 105-123.

Wiratri, A. (2018). Menilik Ulang Arti Keluarga Pada Masyarakat Indonesia (Revisiting The Concept Of Family In Indonesian Society). 13(1), 15-26.

Yuliana, I. (2012). Studi Komparasi antara lbu yang Bekerja dan yang Tidak Bekerja Terhadap Prestasi Belajar Siswa Kelas XI di SMA Negeri I Suwawa. 1, 2012. 